\title{
Influence of competition and predation on survival of the hydrilla tip mining midge and its success as a potential augmentative biological control agent of hydrilla
}

\author{
Courtney Stachowiak · Julie Baniszewski · James P. Cuda • Colette St. Mary • \\ Emma N. I. Weeks (i)
}

Received: 20 July 2020/Revised: 22 October 2020/Accepted: 9 November 2020/Published online: 23 November 2020 (C) The Author(s) 2020

\begin{abstract}
Hydrilla verticillata is an aquatic weed that grows densely throughout the water column and is costly to manage. The hydrilla tip mining midge, Cricotopus lebetis, a potential augmentative biological control agent of hydrilla, feeds on the apical meristem preventing growth. The goal of this study was to quantify the influence of a predator (mosquitofish, Gambusia sp.) and a competitor (hydrilla leafcutter moth, Parapoynx diminutalis) and their interactions, on the ability of the midge to survive and feed on hydrilla. The first experiment involved six treatments established in $37.8 \mathrm{~L}$ tanks with combinations of the organisms, including larval C. lebetis. Survival to adult midge eclosion was significantly reduced in the presence of the predator but was unaffected by the competitor's presence alone. Apical meristem damage was reduced when both the competitor and predator were present. The second
\end{abstract}

Handling editor: André Padial

C. Stachowiak · J. Baniszewski .

J. P. Cuda · E. N. I. Weeks ( $\square)$

Entomology and Nematology Department, University of

Florida, 1881 Natural Area Drive, Bldg. 970,

PO Box 110620, Gainesville, FL 32611-0620, USA

e-mail: eniweeks@ufl.edu

C. St. Mary

Department of Biology, University of Florida, 220

Bartram Hall, PO Box 118525, Gainesville,

FL 32611-8525, USA experiment included four treatments with $C$. lebetis egg masses or larvae and the presence or absence of mosquitofish. Adding C. lebetis as eggs rather than as larvae increased midge survival in the absence of the predator. Midge survival was lower when larvae were added, but the predator had no additional effect. To facilitate successful establishment of the midge and control of hydrilla, high numbers of larvae should be released to overcome predation.

Keywords Invasive plant management - Cricotopus lebetis - Gambusia · Parapoynx diminutalis . Mosquitofish

\section{Introduction}

Hydrilla (Hydrilla verticillata [L.f.] Royle; Hydrocharitaceae) is a rapidly growing aquatic plant native to parts of Asia, Africa, Europe, and Australasia. It has become invasive in the Americas, where it causes concern because of its ecological and economic impacts (Langeland, 1996). Hydrilla is a submerged plant that can grow at deeper depths (up to $15 \mathrm{~m}$ ) than native plants and can also outcompete native plants in shallower water (Gordon, 1998) because of its rapid growth. Individual shoots of hydrilla plants can grow vertically up to $10 \mathrm{~cm}$ per day and three dimensionally almost $5 \mathrm{~m}$ per day (Glomski \& Netherland, 2012). 
Hydrilla forms areas of dense growth throughout the water column and is difficult to remove, which leads to expensive control efforts that often result in failures. For example, one of the most affected states in the USA, Florida, spends approximately US \$10 million annually to control hydrilla in its freshwater systems (FWC, 2018).

Herbicides, mechanical removal, and biological control are used to control hydrilla (Langeland et al., 2012). Herbicides can be effective, but the accumulation of chemicals in the environment and the need for multiple costly treatments limit the practicality of their use. Furthermore, hydrilla has become increasingly resistant to the active ingredients that are approved for use in aquatic systems (Michel et al., 2004). Although mechanical harvesting of hydrilla is a method used in some systems, it is expensive and needs to be repeated up to six times per year due to hydrilla's rapid growth (Langeland, 1996). Hydrilla fragments that may remain following mechanical harvesting can float to areas not previously infested and sprout to produce new plants (Langeland \& Sutton, 1980; Baniszewski et al., 2016a). Grass carp [Ctenopharyngodon idella (Cuvier and Valenciennes, 1844)] (Cyprinidae) are used in hydrilla management when permitted by law (Langeland et al., 2012). However, the release of grass carp in the United States is regulated because it feeds indiscriminately and voraciously on both native and non-native vegetation (Hanlon et al., 2000; Weeks \& Hill, 2014). In contrast, herbivorous insects are often more specialized and have been effective as biological control agents of other aquatic weeds (Winston et al., 2014).

In 1992, a potential augmentative biological control agent for hydrilla was discovered when chironomid larvae were observed feeding on the apical meristems of hydrilla plants in the Crystal River (Florida, USA) watershed (Cuda et al., 2002). Hydrilla growth was reduced at locations where the midges were feeding in the plant. The species was identified as Cricotopus lebetis Sublette, 1964 (Diptera: Chironomidae; hydrilla tip mining midge). The presence of this chironomid midge in Florida was first documented in the mid-1970s, and it is now present in many water bodies in Florida (Stratman et al., 2013a). However, its origin (native or exotic) is not known to date despite morphological and genetic typing studies (Epler et al., 2000; Gresens et al., 2017). The life history of $C$. lebetis and its impact on hydrilla have been studied in the field and laboratory by the University of Florida's Entomology and Nematology Department, finding that the midge is an effective augmentative biological control agent (Cuda et al., 2002, 2011, 2016; Stratman et al., 2013a, b, 2014; Baniszewski et al., 2015, 2016b, 2020; Mitchell et al., 2018).

To better understand the success of $C$. lebetis as a biological control agent, we aimed to understand how natural competitors and predators affected populations. Although these interactions have been studied with other organisms, research to date is limited and highly dependent on the system. An example of competition limiting the efficacy of a biological control agent was seen with Galerucella calmariensis (Linnaeus, 1767) and Galerucella pusilla (Duftschmid, 1825) (Coleoptera: Chrysomelidae), two leaf beetle species used to control purple loosestrife (Pearson \& Callaway, 2005). Galerucella calmariensis was found to establish at all the release sites where G. pusilla failed to establish. The weevil Neohydronomus affinis Hustache, 1926 (Coleoptera: Curculionidae) and the planthopper Lepidelphax pistiae Remes Lenicov and Walsh, 2013 (Hemiptera: Delphacidae) were compatible when used for water lettuce, Pistia stratiotes L. (Araceae), management in Argentina (Cabrera Walsh \& Maestro, 2016). Likewise, the mirid Eccritotarsus catarinensis (Carvalho, 1948) (Heteroptera: Miridae) and the weevil Neochetina eichhorniae Warner, 1970 (Coleoptera: Curculionidae) appeared to be compatible against water hyacinth, Pontederia crassipes (Mart.) Solms-Laub. (Pontederiaceae) (Ajuonu et al., 2009). To fully understand the influence of competition, studies should be completed with the organisms alone and in combination while controlling abiotic factors.

Predation can severely impact the success and establishment of biological control agents. The influence of predation on biological control agents has been observed with the aquatic weevil, Euhrychiopsis lecontei (Dietz, 1896) (Coleoptera: Curculionidae), a biological control agent of Eurasian watermilfoil (Myriophyllum spicatum L.; Haloragaceae) in Minnesota (Sutter \& Newman, 1997; Newman \& Biesboer, 2000). In two lakes, the guts of two sunfish species (Lepomis spp; Centrarchidae) contained both larvae and adults of E. lecontei. Consequently, high densities of sunfish and other predators can limit populations of aquatic insects, including biocontrol agents. 
Understanding the impact of other organisms on an augmentative biological control agent in a natural setting is important to ensure the success of the program. Cricotopus lebetis females lay linear egg masses on the surface of the water from which neonates emerge within $48 \mathrm{~h}$ (Cuda et al., 2002). The neonates swim to locate an apical meristem for feeding. Following larval development, the midge enters the pupal stage. After $24-48 \mathrm{~h}$, the pupa exits the stem and swims to the surface where the adult emerges from the puparium (Cuda et al., 2002). The insect is most vulnerable to competition during the larval feeding stage and to predation during the stages that occur outside the apical meristem: egg, neonate, pupa, and emerging adult. The adventive hydrilla leafcutter moth (Parapoynx diminutalis Snellen, 1880; Lepidoptera: Crambidae) was found in Florida in 1976 (Del Fosse et al., 1976). Although a generalist, and therefore not a good candidate for biological control of hydrilla (Buckingham \& Bennett, 1989), P. diminutalis feeds heavily on hydrilla, and competition between the two species for food has been observed in the laboratory and in the field (Baniszewski et al., 2016b). Severe defoliation due to $P$. diminutalis has been observed, resulting in the loss of all vegetative tissue except for the stems, which has negative effects on C. lebetis in colony situations (Weeks, pers. obs.). Hydrilla leaf cutter moths are likely to be most vulnerable to predation when preparing their cocoons. Fish predation is known to limit populations of hydrilla leaf cutter moth (Perkins, 1978). A potential predator of both the hydrilla tip mining midge and the hydrilla leaf cutter moth are mosquitofish, Gambusia spp (Poecillidae). Mosquitofish feed on larvae and pupae of aquatic invertebrates and insects near the surface of the water (Pyke, 2005). Gambusia spp. are efficient and opportunistic predators, and therefore likely to be non-selective between the hydrilla tip mining midge and the hydrilla leafcutter moth.

Consequently, the goal of this study was to quantify predation, competition, and their interactions on potential survival and efficacy of the augmentative hydrilla biological control agent $C$. lebetis. This was accomplished through two experiments, the first tested if the presence of the predator or competitor affected C. lebetis eclosion or hydrilla damage. The second experiment tested if the release of $C$. lebetis as eggs or larvae affected midge survival in the presence and absence of a predator.

\section{Materials and methods}

Organisms

Hydrilla used in the experiment and for rearing of $C$. lebetis and $P$. diminutalis was collected from ponds at the University of Florida Institute of Food and Agricultural Sciences (UF/IFAS) Center for Aquatic and Invasive Plants (CAIP; $29.72639^{\circ} \mathrm{N}$, $82.41778^{\circ} \mathrm{W}$ ). Hydrilla stem tips ( $\sim 12 \mathrm{~cm}$ long) were rinsed and sonicated to remove and kill any organisms on the stem tips. All other plant materials were discarded. These tips were used in experiments and for rearing the insects. Tips for use in experiments were visually inspected for the presence of the apical meristem and for no damage that was evident to the naked eye. Damaged tips or those without the apical meristem were discarded or used in rearing, the latter used for rearing $P$. diminutalis only.

For rearing both organisms, the stem tips were placed in plastic trays $\left(11.4 \mathrm{~L}\right.$ Sterilite ${ }^{\circledR}, 39.7$ $\mathrm{L} \times 31.4 \mathrm{~W} \times 15.2 \mathrm{H} \mathrm{cm})$ containing well water aerated with a pump and confined within an insect cage made of a PVC frame covered with fine mesh $(61 \times 61 \times 61 \mathrm{~cm})$ as described by Cuda et al. (2002). The cages were held in a greenhouse at the UF/IFAS Entomology and Nematology Department at 21 to $38^{\circ} \mathrm{C}$, and $14: 10 \mathrm{~h} \mathrm{~L}: \mathrm{D}$.

For C. lebetis rearing, egg masses comprising a total of $\sim 1,500$ eggs were added to a plastic tray containing approximately 2,000 hydrilla stem tips submerged in well water. Eclosed adult $C$. lebetis were collected daily using a mouth aspirator with HEPA filter and transferred to an oviposition chamber comprising a 500-ml stopcock separatory funnel containing $\sim 200 \mathrm{~mL}$ of well water (Mitchell et al., 2018). Prior to use in the funnel, hydrilla was added to the well water as an oviposition attractant and left to soak for at least $24 \mathrm{~h}$. The well water was filtered before use to remove large debris. The room that housed the oviposition chambers was maintained at $23^{\circ} \mathrm{C}, 21 \% \mathrm{RH}$, and $14: 10 \mathrm{~h} \mathrm{~L}: \mathrm{D}$. Within the chamber, C. lebetis mated and laid eggs. The eggs were collected the following day (Cuda et al., 2002; Mitchell et al., 2018) and were quantified for total number of eggs (fecundity) and number of fertile eggs (fertility) using a dissecting microscope at $8 \times$ magnification. Following counting, eggs used in experiments were placed in glass vials and relocated to the 
tanks. To obtain larvae for experiments, an egg strand of approximately 100 fertile eggs was placed in a glass vial. After 2-3 days the larvae hatched and could be placed in the tanks as neonates.

Moths ( $P$. diminutalis) used in the experiment were collected at UF/IFAS CAIP and maintained in a colony at the UF/IFAS Entomology and Nematology Department under the greenhouse conditions described previously. To collect moths, hydrilla samples from the field site were examined for larvae or pupae. Field-collected caterpillars were placed onto field-collected hydrilla and monitored daily for adult eclosion. Newly eclosed adults were placed in cages with fresh hydrilla for mating and oviposition. For moth rearing, hydrilla was replaced frequently due to heavy defoliation. Fifth instars (head capsule size of $\sim 0.8 \mathrm{~mm}$ in width; Buckingham \& Bennett, 1996) were handpicked from the plants for experiments.

Fish were collected and held under UF Institute of Animal Use and Care Committee protocol number 201307914. Fish were collected using dip nets in the ponds at UF/IFAS CAIP and were identified as Gambusia holbrooki Girard, 1859 (Poecillidae) based on the collection location and using external characteristics. Only female fish were collected, and sex was confirmed by the lack of the copulatory organ that is present on the male's anal fin. The fish were acclimatized for 2 weeks in a $37.8 \mathrm{~L}$ tank with approximately $3 \mathrm{~cm}$ of sediment at the UF Biology Department. The tanks were on shelves lighted on a fixed photoperiod (14:10 h, L:D). Room temperature varied from 26 to $29^{\circ} \mathrm{C}$. Fish were fed flaked fish food daily during acclimatization and experimentation to ensure that they had adequate food to survive the test and were all at the same state of hunger during testing.

\section{Stocking density}

Stocking densities were selected in an attempt to avoid extreme situations of competition and predation. Approximately 100 C. lebetis were placed in each tank because that is the typical size of an egg mass (Cuda et al., 2002; Baniszewski et al., 2020). To provide sufficient food for the midges, 200 hydrilla tips were added per tank as $C$. lebetis are known to damage up to two tips per larvae during development (Baniszewski et al., 2020). Compared to C. lebetis, $P$. diminutalis is a voracious feeder, so only 10 moth larvae were added to each tank. Based on observations during rearing of both insects, it was estimated that ten moth larvae would produce some general damage of the 200 tips without full defoliation, which would result in a total absence of food for C. lebetis (Weeks, pers. obs.). Three female fish were added to each tank with a predator treatment. Female fish were selected as they have a higher prey drive than their male counterparts that also are focused on mating. Three fish were selected based on a simple calculation that mosquitofish have been observed to consume 14 mosquito larvae per fish in $24 \mathrm{~h}$ (Billman et al., 2007). If each of three fish consumes 14 neonate midge larvae before they can access a hydrilla tip then that still leaves approximately $50 \%$ of the midge population to develop. All fish selected for use were of similar size and were randomly allocated to tanks.

\section{Bioassay}

For both experiments, $37.8 \mathrm{~L}$ fish tanks were filled with well water and fitted with an aeration pump, hydrilla tips, and approximately $2.5 \mathrm{~cm}$ of gravel. The water level was maintained approximately $7.5 \mathrm{~cm}$ from the top of the tank. The tanks were on shelves lighted on a fixed photoperiod (14:10 h, L:D) and placed inside netted cages to prevent escape of insects. Room temperature varied from 26 to $29^{\circ} \mathrm{C}$.

Effect of competition and predation on midge larvae

\section{Treatments}

Each tank received one of six treatments involving different combinations of hydrilla, midge, moth, and fish (Fig. 1). Five replicates were completed, each with a new generation of midge and moth, and recently collected fish and hydrilla. All treatments contained 200 hydrilla tips. The control treatment contained only water and hydrilla. The "midge" treatment included 100 midge larvae. The "midge + moth" treatment had $\sim 100$ midge larvae and 10 moth larvae. The "midge + fish" treatment had $\sim 100$ midge larvae and three female fish. The "midge + moth + fish" treatment combined $\sim 100$ midge larvae, 10 moth larvae, and three female fish. The final treatment, "moth," contained only the hydrilla and 10 moth larvae. For each replicate, the hydrilla, 


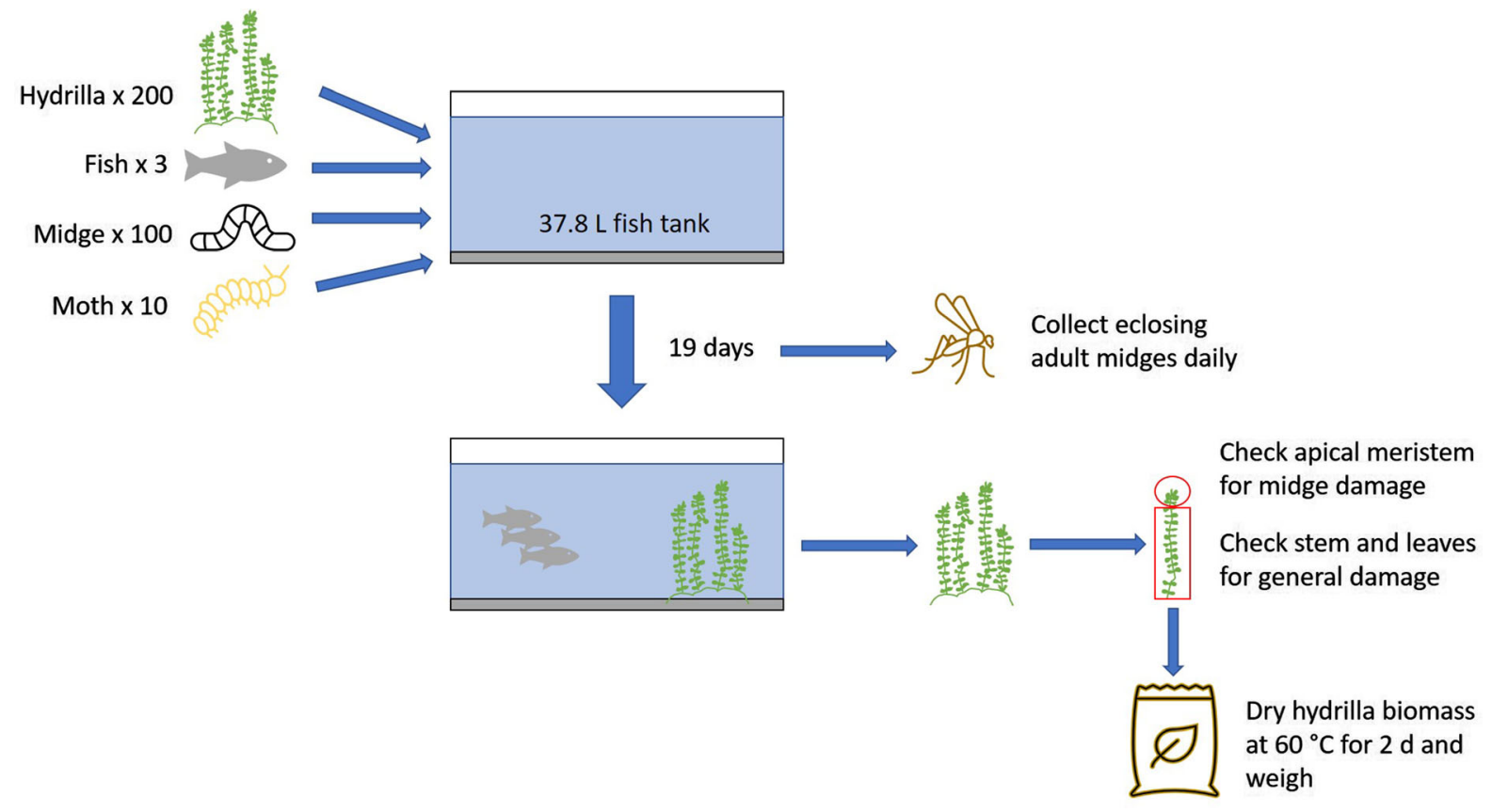

Fig. 1 Schematic showing the experimental design to test the effect of competition and predation on hydrilla tip mining midge, Cricotopus lebetis. Combinations of organisms were placed in fish tanks with Hydrilla verticillata including the midge (C. lebetis), with a moth competitor (Parapoynx

fish, midge larvae, and moth larvae were added to tanks on the same day.

\section{Data collection}

The number of adult midges that eclosed daily was recorded for one generation (19 days) after treatments were added to tanks. Percentage eclosion of adult midges was calculated from the number of fertile eggs; all fertile eggs were assumed to result in freeswimming neonates. To assess hydrilla damage, each hydrilla tip was observed under a stereomicroscope with LED illumination at $8 \times$ magnification. Two damage variables were reported as presence or absence: apical meristem damage and general damage. If any feeding damage was found at the apical meristem, this damage was considered to be due to $C$. lebetis feeding due to its known preference for feeding in this part of the plant and was classified as "apical meristem damage." If any feeding was visible on the leaves throughout the stem but not specifically on the apical meristem, the tips were determined to have "general damage" that was likely due to feeding by diminutalis), and a fish predator (Gambusia holbrooki). Midge eclosion, apical meristem damage, general damage, and hydrilla biomass were recorded. The second experiment followed the same design but only fish and midge were added to the tanks and damage/biomass data were not collected

the competitor. It was possible for a tip to have both apical meristem damage and general damage present if herbivory was present in both areas. Biomass data were collected by first air drying the hydrilla for 7 days. The hydrilla from each tank was then placed in a paper bag, and all bags were put into a drying oven at $60^{\circ} \mathrm{C}$ for 2 days. The dry hydrilla was then weighed (g) using a Denver Instrument Company XD-2KD digital scale (Denver, CO).

\section{Statistical analysis}

All variables were tested for normality using the Shapiro-Wilk test. Percentage eclosion and apical meristem damage to hydrilla did not follow a normal distribution. Therefore, data were analyzed by the non-parametric Kruskal-Wallis test. Non-parametric means comparisons were completed using the Wilcoxon rank-sum test $(\alpha=0.05)$. Dry weight and general damage were found to be normally distributed and were analyzed using an ANOVA with Tukey's honestly significant difference (HSD) test to compare means $(\alpha=0.05)$. All analyses were completed using 
JMP $^{\circledR}$ Pro version 13 software (SAS, 2017). Means with standard errors of the mean were reported in results and figures.

Effect of predation on midge eggs versus larvae

\section{Treatments}

There were four treatments comprising a two-way factorial design of eggs, eggs + fish, larvae, and larvae + fish (Fig. 1). All tanks contained 200 hydrilla tips and approximately 100 midges were added as eggs or larvae (prepared as described previously). Three female fish were added to half of the egg and larvae treatments. The experiment was replicated three times, each replicate using a new generation of $C$. lebetis and freshly collected hydrilla and fish.

\section{Data collection}

The number of adult midges that eclosed each day was recorded for one generation (19 days) after treatments were added to tanks. Percentage eclosion of adult midges from the number of fertile eggs or larvae added was calculated.

\section{Statistical analysis}

Normality was assessed by studying the residual plots, and percentage eclosion was determined to be normally distributed. Therefore, data were analyzed by fitting a generalized linear model for a binomial distribution with a logit link with the fixed factors of stage (eggs or larvae) and predator (present or absent). Least significant differences tests were used to compare means $(\alpha=0.05)$. Analyses were completed using SAS (SAS, 2009). Means with standard errors of the mean were reported in results and figures.

\section{Results}

Effect of competition and predation on midge larvae

\section{Adult eclosion}

There was a significant effect of treatment on adult midge eclosion (Kruskal-Wallis $\chi^{2}=25.95$, df $=5$,
$P<0.0001)$. Percentage eclosion was significantly reduced in treatments with fish from $41.7 \pm 3.5 \%$ (mean $\pm \mathrm{SE}$ ) in the midge treatment to $15.8 \pm 4.4 \%$ and $12.1 \pm 6.4 \%$ in the midge + fish and midge + moth + fish treatments, respectively (Fig. 2, $P<0.05, n=5$ ). There were no statistical differences in adult midge eclosion between the midge and the midge + moth treatment (Fig. $2, P>0.05, n=5$ ).

\section{Hydrilla damage assessment}

Apical meristem damage was clearly associated with midge presence, as expected due to their known predilection for this feeding site. There was minimal apical meristem damage recorded when the midges were not introduced into the tanks (i.e., control $[0.8 \pm 10.1$ tips damaged, mean $\pm \mathrm{SE}]$ and moth $[1.0 \pm 10.1$ tips damaged] treatments), probably incidental or background damage that occurred in the field prior to collection of plant material. There was a significant effect of treatment on apical meristem damage (Fig. 3, Kruskal-Wallis $\chi^{2}=18.40$, df $=$ $5, P=0.0025, n=4)$. There was a significant reduction in apical meristem damage in the presence of both the predator and the competitor (midge + moth + fish treatment) compared with the presence

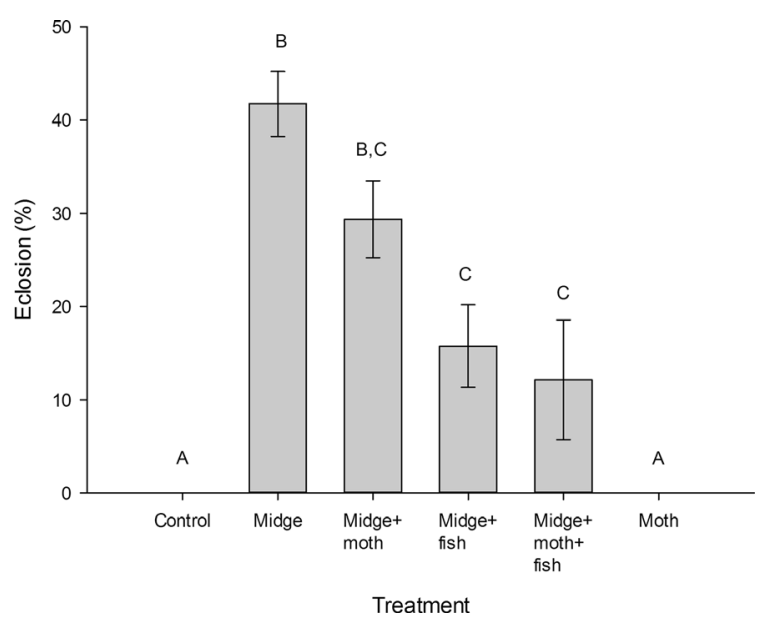

Fig. 2 Percentage eclosion of adult hydrilla tip mining midge, Cricotopus lebetis, from hydrilla (Hydrilla verticillata) in tank tests with predation by mosquitofish, Gambusia sp., and competition from the hydrilla leafcutter moth, Parapoynx diminutalis. Bars represent mean percentages \pm SE (KruskalWallis $\chi^{2}=25.95$, $\mathrm{df}=5, P<0.0001, n=5$ ). Different letters above bars indicate significant differences among the means $(P<0.05)$ 
of the midge alone: $37.5 \pm 10.1$ and $92.3 \pm 10.1$ tips damaged, respectively. Damage to the apical meristem of hydrilla also was reduced when either a competitor (midge + moth; $54.5 \pm 10.1$ tips damaged) or predator (midge + fish; $57.8 \pm 10.1$ tips damaged) was present relative to the midge treatment. Although there was less apical meristem damage when both the competitor and predator were present, this difference was not statistically different to either the competitor or predator alone.

General damage to the 200 hydrilla stems was not statistically different among any of the treatments (Fig. 4, ANOVA $\mathrm{F}=1.9316$, df $=5, P=0.1388$, $n=4)$. However, the number of stems with general damage was greater when moths were present (i.e., in the moth, midge + moth, and midge + moth + fish treatments; 96-117 tips damaged) compared to when moths were absent (45.8-66.3 tips damaged).

There was no statistical difference in the dry weight (g) between the treatments (ANOVA $\mathrm{F}=0.1404$, df $=5, P=0.9761)$. However, the amounts assessed were low (200 tips, average $3.98 \pm 0.17 \mathrm{~g}$ dry weight, $n=24$ ) and the experiment was possibly too short to see a significant impact on this variable. The treatment with the lowest average biomass $(3.73 \pm 0.59 \mathrm{~g}$, $n=4$ ) was the three-organism combination, midge +

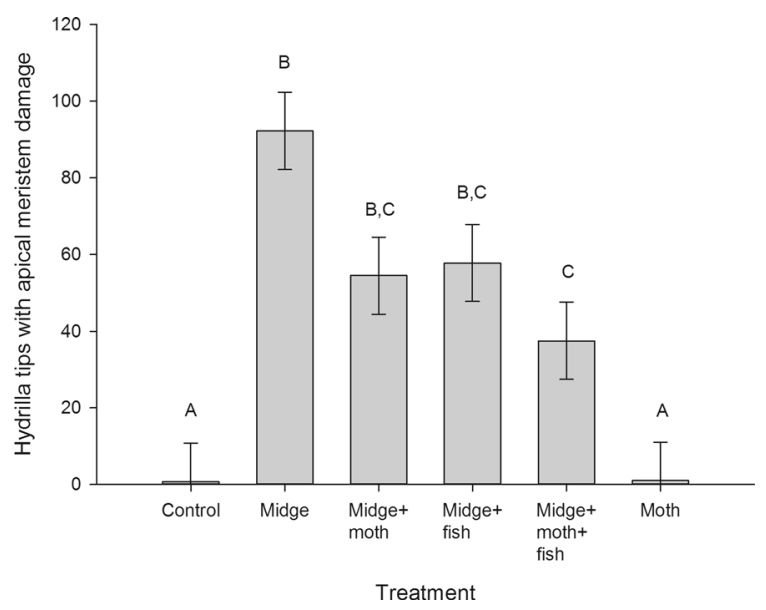

Fig. 3 Number of hydrilla (Hydrilla verticillata) stems (200 hydrilla stems per treatment) with apical meristem damage caused by feeding of hydrilla tip mining midge (Cricotopus lebetis) in tank tests. Bars represent mean \pm SE (KruskalWallis $\chi^{2}=18.40$, df $\left.=5, P=0.0025, n=4\right)$. Different letters above bars indicate significant differences among the means $(P<0.05)$

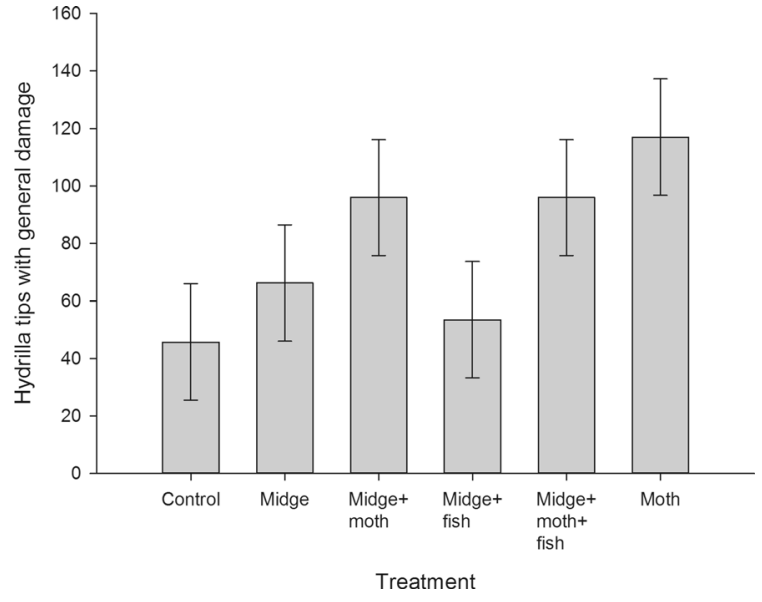

Fig. 4 Number of hydrilla (Hydrilla verticillata) stems (200 hydrilla stems per treatment) with general damage from feeding by herbivores other than hydrilla tip mining midge (Cricotopus lebetis) in tank tests. Bars represent mean \pm SE (ANOVA $\mathrm{F}=1.9316, \mathrm{df}=5, P=0.1388, n=4)$

moth + fish. The greatest average biomass $(4.33 \pm 0.42 \mathrm{~g}, n=4)$ was the moth treatment.

\section{Effect of predation on midge eggs versus larvae}

There was a significant effect of the interaction between fish and life stage added to the tank on adult eclosion (Analysis of Deviance $\mathrm{F}=9.45$, $\mathrm{df}=1,5$, $P=0.0276, n=3)$. Eclosion of adult midges was reduced when $C$. lebetis were added to tanks as larvae $(21.7 \pm 3.5 \%$; mean $\pm \mathrm{SE})$ instead of as eggs $(41.8 \pm 5.8 \%)$ in the absence of fish (Fig. 5). The presence of the predator had a significant negative effect on adult eclosion if eggs were added $(12.0 \pm 2.7 \%)$ but not if larvae $(17.7 \pm 3.2 \%)$ were added.

\section{Discussion}

This study measured the effects of competition and predation on the hydrilla tip mining midge. When exposed to mosquitofish, Gambusia sp., a predator of C. lebetis, adult midge eclosion was reduced and hydrilla apical meristem damage caused by $C$. lebetis decreased. The hydrilla leaf cutter moth, $P$. diminutalis, a known competitor of the midge, did not negatively impact the survival of the midge or the damage it induced on hydrilla. In the absence of the 


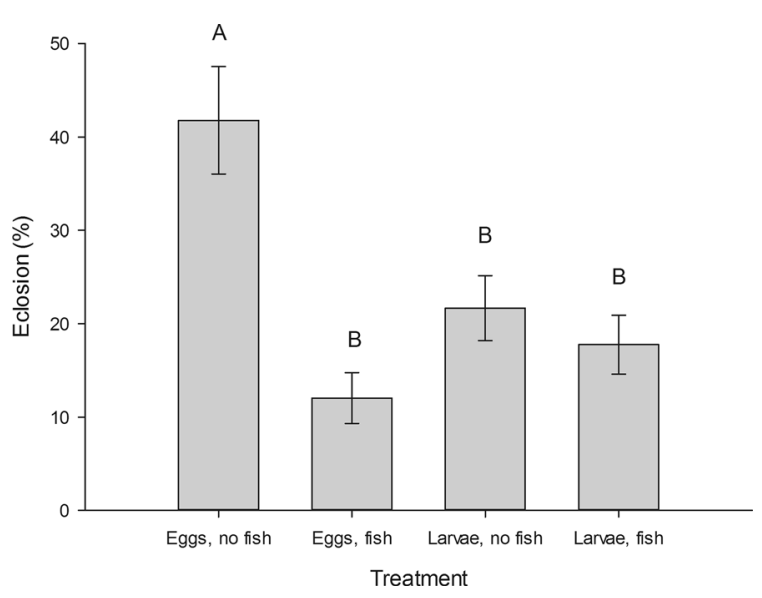

Fig. 5 Eclosion (\%) of adult hydrilla tip mining midge, Cricotopus lebetis, from hydrilla (Hydrilla verticillata) in tank tests with predation by mosquitofish (Gambusia sp.) on $C$. lebetis eggs or larvae added to the tanks. Bars represent mean percentages $\pm \mathrm{SE}$ (Analysis of Deviance $\mathrm{F}=9.45$, $\mathrm{df}=1,5$, $P=0.0276, n=3)$. Different letters above bars indicate significant differences among the means $(P<0.05)$

predator, midge survival was significantly lower when midges were added as larvae rather than as an egg mass. In the presence of the predator, there was a significant negative effect on survival when the midges were added as an egg mass but not when they were added as neonate larvae.

Damage to apical meristems was assessed to determine the potential effect of the predator and competitor on the consumption of hydrilla by the midge. Apical meristem damage was clearly associated with the presence of $C$. lebetis as expected due to their known preference for feeding in this area of hydrilla (Cuda et al., 2002). The number of hydrilla tips with apical meristem damage in the presence of $C$. lebetis was approximately $50 \%$ corresponding to approximately one apical meristem damaged per larvae introduced. However, when the midge was absent, $0.5 \%$ of apical meristems appeared to have some feeding damage. This damage was very minimal and likely occurred prior the study as no C. lebetis eclosed from the treatments without midges added.

Assessment of general damage to the stem was completed to determine herbivory by the competitor. There was no significant difference between treatments, indicating that the moth competitor was not consistently consuming hydrilla. Although the number of tips with general damage was slightly elevated in the treatments with moths, the differences were not significant when compared with treatments without moths. This was a surprising result as $P$. diminutalis is known to actively consume hydrilla (Buckingham \& Bennett, 1996), and defoliation of hydrilla by the moth can occur over a similar time frame (19 days) in the laboratory setting (Baniszewski et al., 2016b).

Our first experiment revealed that predation reduced midge survival and midge hydrilla consumption. Midge survival to adult eclosion was reduced in the presence of a fish predator by more than $50 \%$, indicating that consumption of larvae or pupae by mosquitofish occurred. The fish did not select the moth over the midge as midge eclosion was the same in the presence of the fish regardless of the presence of the moth, which is not surprising given the preference of mosquitofish for chironomids over other insects (Blanco et al., 2004). Furthermore, apical meristem damage was significantly lower in the midge + moth + fish treatment when compared to the midge treatment. As both apical meristem damage and percentage eclosion were significantly lower, we can assume the midges were preyed upon as early instars. Alternatively, if there had been no difference in apical meristem damage to the hydrilla with reduced adult eclosion, we would have inferred that the midges were fed on at the pupal stage or as newly eclosed adults emerging from the water.

Our second experiment examined the effect of predation on different life stages of the hydrilla tip mining midge. In the absence of a predator, midge survival was reduced when added as larvae but not when added as eggs. This effect is possibly due to the stress induced by the change in conditions from the small holding container to the tank and would be similar in a field release situation. In the presence of a predator, midge survival was reduced when added as eggs but not when midges were added as larvae. This reduction in eclosion could be a result of the fish feeding on large portions of the gelatinous egg strand as opposed to having to hunt for the mobile midge larvae. However, it is important to note that as survival was lower when larvae were released compared to when eggs were added in the absence of a predator, in the presence of the predator the survival between the two groups was statistically equivalent. Although this result implies that either could be released without an effect on survival, release of larvae might be less likely to result in consumption of the entire brood. Evidence suggests that Gambusia spp. may prefer to feed on 
larger aquatic invertebrates (Bence \& Murdoch, 1986) and are visual predators (Lounibos et al., 1992). Because an egg mass is larger than an individual larva, the egg mass may have been easier to locate and more efficient to consume. Midge egg strands used in this study were approximately $17 \mathrm{~mm}$ in length and neonates were approximately 0.4 to $0.6 \mathrm{~mm}$ (unpublished data). Therefore, when conducting release of midges for hydrilla control, releasing larvae after they have hatched should be considered to minimize predation and maximize efficacy.

One limitation of the study was the pre-existing damage in the hydrilla. Although attempts were made to only use healthy undamaged hydrilla tips, as they were field collected, the presence of background herbivory that occurred prior to use in the experiment was inevitable. This may have negated the possibility of detecting significant damage differences in the experiments. Future studies should examine the tips microscopically prior to incorporation in the study and consider using a scale for the amount of damage rather than the presence or absence of damage.

\section{Conclusion}

Management of hydrilla has involved large investments of money and time. Limitations of mechanical removal, herbicides, and biological control have led to the study of the hydrilla tip mining midge, C. lebetis, as a new biological component for integrated pest management programs of hydrilla. In both experiments, survival of the hydrilla tip mining midge was dramatically impacted by mosquitofish predation. In natural freshwater bodies, the hydrilla tip mining midge would be subject to predation from fish or other predators as well as competitors, such as $P$. diminutalis. The results of this study showed that the strong influence of predation on the midge could limit its ability to successfully feed on hydrilla to decrease plant growth. To counteract the impact that predation has on the survival of the midge, increasing the size or number of releases to compensate for predation would likely be beneficial. In conjunction, other techniques to protect the larvae from predation, such as nocturnal releases to avoid predation or fish free inoculation zones, would allow for the midge to successfully establish in natural water bodies.
Acknowledgements The authors would like to acknowledge funding provided by the United States Department of Agriculture, National Institute of Food and Agriculture (USDA-NIFA) Risk Avoidance and Mitigation Competitive Grants Program 2010-02825, and the USDA-NIFA Crop Protection and Pest Management Competitive Grants Program, Applied Research and Development Program Area 2014-70006-22517. The authors would also like to extend their appreciation to members of the Biological Control Laboratory at the UF/IFAS Entomology and Nematology Department for support with colony maintenance and experiments, particularly Rachel Watson, Adriana Mitchell, Eutychus Kariuki, and Alissa Berro. Additionally, the authors would like to thank Arthur Randolph (University of Florida Department of Biology) for assistance with setting up the experiments and advice on fish health and welfare.

Open Access This article is licensed under a Creative Commons Attribution 4.0 International License, which permits use, sharing, adaptation, distribution and reproduction in any medium or format, as long as you give appropriate credit to the original author(s) and the source, provide a link to the Creative Commons licence, and indicate if changes were made. The images or other third party material in this article are included in the article's Creative Commons licence, unless indicated otherwise in a credit line to the material. If material is not included in the article's Creative Commons licence and your intended use is not permitted by statutory regulation or exceeds the permitted use, you will need to obtain permission directly from the copyright holder. To view a copy of this licence, visit http://creativecommons.org/licenses/by/4.0/.

Data availability The datasets generated and analyzed during the current study are available by contacting the corresponding author.

\section{References}

Ajuonu, O., M. Byrne, M. Hill, P. Neuenschwander \& S. Korie, 2009. The effect of two biological control agents, the weevil Neochetina eichhorniae and the mirid Eccritotarsus catarinensis on water hyacinth, Eichhornia crassipes, grown in culture with water lettuce, Pistia stratiotes. BioControl 54: 155-162.

Baniszewski, J., E. N. I. Weeks \& J. P. Cuda, 2015. Impact of refrigeration on eggs of the hydrilla tip mining midge Cricotopus lebetis (Diptera: Chironomidae): larval hatch rate and subsequent development. Journal of Aquatic Plant Management 53: 209-215.

Baniszewski, J., J. P. Cuda, S. A. Gezan, S. Sharma \& E. N. I. Weeks, 2016a. Stem fragment regrowth of Hydrilla verticillata following desiccation. Journal of Aquatic Plant Management 54: 53-60.

Baniszewski, J., E. N. I. Weeks \& J. P. Cuda, 2016b. Bacillus thuringiensis subspecies kurstaki reduces competition by Parapoynx diminutalis (Lepidoptera: Crambidae) in colonies of the hydrilla biological control agent Cricotopus 
lebetis (Diptera: Chironomidae). Florida Entomologist 99: 644-647.

Baniszewski, J., N. Miller, E. Kariuki, J. P. Cuda \& E. N. I. Weeks, 2020. Apical meristem damage of hydrilla by the tip mining midge, Cricotopus lebetis. Florida Entomologist 103: 32-37.

Bence, J. R. \& W. W. Murdoch, 1986. Prey size selection by the mosquitofish: relation to optimal diet theory. Ecology 67: 324-336.

Billman, E. J., E. J. Wagner \& R. E. Arndt, 2007. A comparison of mosquito consumption and prey selection between least chub (Zotzchthys phlegethontzs) and western mosquitofish (Gambusia affinis). Western North American Naturalist 67: 71-78.

Blanco, S., S. Romo \& M.-J. Villena, 2004. Experimental study on the diet of mosquitofish (Gambusia holbrooki) under different ecological conditions in a shallow lake. International Review of Hydrobiology 89: 250-262.

Buckingham, G. R. \& C. A. Bennett, 1989. Laboratory host range of Parapoynx diminutalis (Lepidoptera: Pyralidae), an Asian aquatic moth adventive in Florida and Panama on Hydrilla verticillata (Hydrocharitaceae). Environmental Entomology 18: 526-530.

Buckingham, G. R. \& C. A. Bennett, 1996. Laboratory biology of an immigrant Asian moth, Parapoynx diminutalis (Lepidoptera: Pyralidae), on Hydrilla verticillata (Hydrochariaeae). Florida Entomologist 79: 353-363.

Cabrera Walsh, G. \& M. Maestro, 2016. Impact of introduced native herbivores on a Pistia stratiotes infestation close to the Paraná Delta in Argentina. Biological Control Science and Technology 26: 35-46.

Cuda, J. P., B. R. Coon, Y. M. Dao \& T. D. Center, 2002. Biology and laboratory rearing of Cricotopus lebetis (Diptera: Chironomidae), a natural enemy of the aquatic weed hydrilla (Hydrocharitaceae). Annals of the Entomological Society of America 95: 587-596.

Cuda, J. P., B. R. Coon, Y. M. Dao \& T. D. Center, 2011. Effect of an herbivorous stem-mining midge on the growth of hydrilla. Journal of Aquatic Plant Management 49: 83-89.

Cuda, J. P., J. F. Shearer, E. N. I. Weeks, E. Kariuki, J. Baniszewski \& M. Giurcanu, 2016. Compatibility of an insect, a fungus and an herbicide for integrated pest management of dioecious hydrilla. Journal of Aquatic Plant Management 54: 20-25.

Del Fosse, E. S., B. D. Perkin \& K. K. Steward, 1976. A new record for Parapoynx diminutalis (Lepidoptera: Pyralidae), a possible biological control agent for Hydrilla verticillata. Florida Entomologist 59: 1-30.

Epler, J. H., J. P. Cuda \& T. D. Center, 2000. Redescription of Cricotopus lebetis (Diptera: Chironomidae), a potential biocontrol agent of the aquatic weed hydrilla (Hydrocharitaceae). Florida Entomologist 83: 171-180.

FWC (Florida Fish and Wildlife Conservation Commission), 2018. Annual report of activities conducted under the Cooperative Aquatic Plant Control Program in Florida Public Waters for Fiscal Year 2017-2018. Florida Fish and Wildlife Conservation Commission Invasive Plant Management Section.

Glomski, L. M. \& M. D. Netherland, 2012. Does hydrilla grow an inch per day? Measuring short-term changes in shoot length to describe invasive potential. Journal of Aquatic Plant Management 50: 54-57.

Gordon, D. R., 1998. Effects of invasive, non-indigenous plant species on ecosystem processes: lessons from Florida. Ecological Applications 8: 975-989.

Gresens, S. E., T. Ekrem, E. Stur \& C. Winters, 2017. Transatlantic Cricotopus sylvestris revisited: population structure or endemic species? $20^{\text {th }}$ International Symposium on Chironomidae, 2-8 July 2017. Trieste, Italy

Hanlon, S. G., M. V. Hoyer, C. E. Cichra \& D. E. Canfield, 2000. Evaluation of macrophyte control in 38 Florida lakes using triploid grass carp. Journal of Aquatic Plant Management 38: 48-54.

Langeland, K. A. \& D. L. Sutton, 1980. Regrowth of hydrilla from axillary buds. Journal of Aquatic Plant Management 18: 27-29.

Langeland, K. A., 1996. Hydrilla verticillata (L.F.) Royle (Hydrocharitaceae), "the perfect aquatic weed". Castanea 61: 293-304.

Langeland, K. A., S. F. Enloe \& L. Gettys, 2012. Hydrilla management in Florida lakes. UF/IFAS Extension SSAGR-361.

Lounibos, L. P., N. Nishimura \& L. B. Dewald, 1992. Predation of Mansonia (Diptera: Culicidae) by native mosquitofish in southern Florida. Journal of Medical Entomology 29: 236-241.

Michel, A., R. S. Arias, B. E. Scheffler, S. O. Duke, M. Netherland \& F. E. Dayan, 2004. Somatic mutation-mediated evolution of herbicide resistance in the nonindigenous invasive plant hydrilla (Hydrilla verticillata). Molecular Ecology 13: 3229-3237.

Mitchell, A., A. Berro, J. P. Cuda \& E. N. I. Weeks, 2018. Impact of food deprivation on hydrilla tip mining midge survival and subsequent development. Florida Entomologist 101: 74-78.

Newman, R. M. \& D. D. Biesboer, 2000. A decline of Eurasian watermilfoil in Minnesota associated with the milfoil weevil, Euhrychiopsis lecontei. Journal of Aquatic Plant Management 38: 105-111.

Pearson, D. E. \& R. M. Callaway, 2005. Indirect nontarget effects of host-specific biological control agents: implications for biological control. Biological Control 35: 288-298.

Perkins, B. D., 1978. Approaches in biological control of aquatic weeds. Proceedings European Weed Research Society, Symposium on Aquatic Weeds, Amsterdam, Netherlands: $9-15$.

Pyke, G. H., 2005. A review of the biology of Gambusia affinis and G. holbrooki. Reviews in Fish Biology and Fisheries 15: 339-365.

SAS (SAS Institute Inc.), 2009. SAS/STAT ${ }^{\circledR} 9.2$ User's Guide, Second Edition. SAS Institute Inc., Cary, North Carolina

SAS (SAS Institute Inc.), 2017. Using JMP 13. SAS Institute Inc., Cary, North Carolina

Stratman, K. N., W. A. Overholt, J. P. Cuda, M. D. Netherland \& P. C. Wilson, 2013a. The diversity of Chironomidae associated with hydrilla in Florida with special reference to Cricotopus lebetis (Diptera: Chironomidae). Florida Entomologist 96: 654-657.

Stratman, K. N., W. A. Overholt, J. P. Cuda, M. D. Netherland \& P. C. Wilson, 2013b. Host range and searching behaviour 
of Cricotopus lebetis (Diptera: Chironomidae), a tip miner of Hydrilla verticillata (Hydrocharitaceae). Biocontrol Science and Technology 23: 317-334.

Stratman, K. N., W. A. Overholt, J. P. Cuda, A. Mukherjee, R. Diaz, M. D. Netherland \& P. C. Wilson, 2014. Temperature-dependent development, cold tolerance and potential distribution of Cricotopus lebetis (Diptera: Chironomidae), a tip miner of Hydrilla verticillata (Hydrocharitaceae). Journal of Insect Science 14: 1-8.

Sutter, T. J. \& R. M. Newman, 1997. Is predation by sunfish (Lepomis spp.) an important source of mortality for the Eurasian watermilfoil biocontrol agent Euhrychiopsis lecontei? Journal of Freshwater Ecology 12: 225-234.

Weeks, E. N. I. \& J. E. Hill, 2014. Grass carp, the white amur (common name) Ctenopharyngodon idella (Cuvier and
Valenciennes) (Actinopterygii: Cyprinidae: Squaliobarbinae). UF/IFAS Extension EENY-593. http://entnemdept. ufl.edu/creatures/BENEFICIAL/MISC/

Ctenopharyngodon_idella.htm

Winston, R. L., M. Schwarzländer, H. L. Hinz, M. D. Day, M. J. W. Cock \& M. H. Julien (Eds), 2014. Biological Control of Weeds: A World Catalogue of Agents and Their Target Weeds, 5th edition, FHTET-2014-04. Morgantown, WV: USDA Forest Service, Forest Health Technology Enterprise Team. p. 838

Publisher's Note Springer Nature remains neutral with regard to jurisdictional claims in published maps and institutional affiliations. 